\title{
Comparison of force degradation and color change of esthetic elastomeric chains
}

\author{
Comparação da degradação da força e da alteração de cor de elásticos corrente estéticos \\ Comparación de la degradación de la fuerza y el cambio de color de las cadenas elastométicas \\ estéticas
}

Received: 03/26/2021 | Reviewed: 04/10/2021 |Accept: 04/12/2021 | Published: 04/22/2021

\author{
Maria Julia Lima Motta \\ ORCID: https://orcid.org/0000-0001-7544-6670 \\ Centro Universitário Sagrado Coração, Brazil \\ E-mail: mariajulia.limamotta @ hotmail.com \\ Victor de Miranda Ladewig \\ ORCID: https://orcid.org/0000-0001-6041-1299 \\ Universidade Norte do Paraná, Brazil \\ E-mail: victor@odontobaby.odo.br \\ Joel Ferreira Santiago Junior \\ ORCID: https://orcid.org/0000-0003-1735-2224 \\ Centro Universitário Sagrado Coração, Brazil \\ E-mail: jf.santiagojunior@gmail.com \\ Renata Rodrigues Almeida-Pedrin \\ ORCID: https://orcid.org/0000-0002-4283-1051 \\ Universidade Norte do Paraná, Brazil \\ E-mail: repedrin@gmail.com \\ Thais Maria Freire Fernandes Poleti \\ ORCID: https://orcid.org/0000-0002-4368-8568 \\ Universidade Norte do Paraná, Brazil \\ E-mail: thais.poleti@unopar.br \\ Ana Claudia de Castro Ferreira Conti \\ ORCID: https://orcid.org/0000-0001-9658-1652 \\ Universidade Norte do Paraná, Brazil \\ E-mail: accfconti@uol.com.br
}

\begin{abstract}
Objective: this study compared the force degradation and color change of esthetic elastomeric chains of four commercial brands. Materials and methods: the study analyzed 10 medium-force esthetic elastomeric chains with 6 links of Morelli, Orthometric, Eurodonto and 3M brands from sealed packages within the expiration date. The elastics were stretched twice their length, according to the manufacturer's recommendations, and were immersed in artificial saliva at $37^{\circ} \mathrm{C}$. The forces were measured with an orthodontic dynamometer at onset and at intervals of $1,7,14,21$ and 30 days after immersion. The force degradation was evaluated calculating the percentage of force lost in relation to the initial force in each time interval, for each group tested separately and also between them. The color change was evaluated by visual analysis scale by observation of photographs of chain elastics before and after study completion by 31 examiners. The ANOVA test of repeated measures was applied considering 2 factors, time and groups, and the Tukey test was used for analysis of multiple comparisons. A significance value of $0.05 \%$ was adopted for the analyses. Results: the elastics showed great force degradation. After 7 days the groups presented degradation around $50 \%$ of the initial force. In the evaluation between groups, the elastics showed significantly different mean forces. When assessing color change, the scores assigned by examiners evidenced less color changes for elastics of Eurodonto brand. Conclusion: regardless of the commercial brand, transparent elastomeric chains show significant force degradation values after 1 day. The scores assigned to color change evidenced that all commercial brands showed staining, with the best results for Eurodonto elastics.
\end{abstract}

Keywords: Orthodontics; Latex; Force; Degradation; Color.

\section{Resumo}

Objetivo: O objetivo deste projeto consistiu em comparar a degradação de força e a alteração de cor de elásticos corrente estéticos de 4 marcas comerciais. Materiais e métodos. Foram avaliados 10 elásticos corrente estético de força média com 6 elos das marcas Morelli, Orthometric, Eurodonto e 3M provenientes de embalagens seladas e dentro do prazo de validade. Os elásticos foram distendidos o dobro de seu comprimento, de acordo com a recomendação do fabricante, e submersos em saliva artificial a 37 graus Celsius. As forças foram mensuradas com dinamômetro ortodôntico ao início e nos intervalos de 1, 7, 14, 21 e 30 dias após a imersão. A avaliação da 
degradação da força foi realizada calculando o percentual de força perdida em relação à força inicial em cada intervalo de tempo, para cada grupo testado separadamente e também entre eles. A avaliação da alteração de cor foi realizada por meio da escala de análise visual na observação de fotografias dos elásticos antes e após o término do experimento por 31 examinadores. Foi adotado o teste ANOVA de medidas repetidas considerando 2 fatores, tempo e grupos e para as análises de múltiplas comparações utilizou-se o teste de Tukey. Foi adotado um valor de significância de 0,05\% para as análises. Resultados: Os elásticos apresentaram grande degradação de força, após 7 dias os grupos apresentaram degradação em torno de $50 \%$ da força inicial. Na avaliação entre os grupos, os elásticos apresentaram médias de força significantemente diferentes. Na avaliação da alteração de cor, os examinadores atribuíram notas considerando os elásticos da marca Eurodonto os que apresentaram menores alterações de cor. Conclusão: Independente da marca comercial os elásticos em cadeia transparente apresentam valores de degradação de força significantes após 1 dia. As notas atribuídas à alteração de cor demonstraram que todas as marcas comerciais apresentaram manchamento, com os melhores resultados para os elásticos da Eurodonto.

Palavras-chave: Ortodontia; Látex ; Força; Degradação; Cor.

\section{Resumen}

Objetivo: El objetivo de este proyecto fue comparar la degradación de la resistencia y el cambio de color de los elásticos de cadena estéticos de 4 marcas comerciales. Materiales y métodos. Se evaluaron 10 elásticos de cadena estética de resistencia media con 6 eslabones de las marcas Morelli, Orthometric, Eurodonto y 3M de envases sellados y dentro del período de validez. Los elásticos se estiraron el doble de su longitud, de acuerdo con la recomendación del fabricante, y se sumergieron en saliva artificial a 37 grados centígrados. Las fuerzas se midieron con un dinamómetro de ortodoncia al inicio y a intervalos de 1, 7, 14, 21 y 30 días después de la inmersión. La evaluación de la degradación de la resistencia se realizó calculando el porcentaje de resistencia perdida en relación con la resistencia inicial en cada intervalo de tiempo, para cada grupo probado por separado y también entre ellos. La evaluación del cambio de color se realizó mediante la escala de análisis visual en la observación de fotografías de las gomas elásticas antes y después del final del experimento por 31 examinadores. Se adoptó la prueba ANOVA de medidas repetidas considerando 2 factores, tiempo y grupos y para el análisis de comparaciones múltiples se utilizó la prueba de Tukey. Se adoptó un valor de significancia de $0.05 \%$ para los análisis. Resultados: Los elásticos mostraron una gran degradación de la resistencia, a los 7 días los grupos presentaron una degradación de alrededor del $50 \%$ de la resistencia inicial. En la evaluación entre los grupos, los elásticos mostraron resistencias medias significativamente diferentes. Al evaluar el cambio de color, los examinadores asignaron puntajes considerando los elásticos de la marca Eurodonto aquellos con los menores cambios de color. Conclusión: Independientemente de la marca comercial, los elásticos de cadena transparentes muestran valores de degradación de resistencia significativos después de 1 día. Las notas atribuidas al cambio de color mostraron que todas las marcas comerciales mostraron manchas, con los mejores resultados para las bandas de goma Eurodonto.

Palabras clave: Ortodoncia; Látex; Resistencia; Degradación; Color.

\section{Introduction}

In recent decades, there has been a greater demand from adult patients in orthodontic clinics. This likely occurred due to greater dissemination and also due to the standpoint of prevention of modern dentistry, increased longevity, greater access to information, advances in orthodontics and psychosocial variations (Tweng et al., 2012; Zhang et al., 2008; Mandall et al., 2006). Even though the esthetic reasons are sufficient to justify this increase in the demand for treatment by adults, which directly results in better self-image of the patient, the esthetic and psychological benefits are more valued than the functional and oral health benefits (Aldrees et al., 2015; Cavalcante et al., 2013).

Within this context, to meet this greater demand from patients with great esthetic needs, the orthodontic appliances and accessories have been improved. Ceramic and self-ligating brackets, aligners and esthetic elastics have been marketed in large scale. Regarding the orthodontic elastics, the elastomeric chains are one of the most important accessories in orthodontic treatment, being mainly used for closure of spaces between teeth (Alexandre et al., 2008; Baty et al., 1994).

An ideal elastic chain should release smooth and continuous forces to obtain greater control over tooth movements, besides presenting adequate characteristics for oral use and providing the desirable tooth movement (Santos et al., 2009; Loriato et al., 2006; Cabrera et al., 2003). Despite the widespread utilization of these accessories, there are some disadvantages related to their use. One of the characteristics inherent to elastics is the force degradation, which is reduced over time, 
decreasing the tooth movement and consequently increasing the treatment time (Fernandes et al., 2011; Moris et al., 2009; Loriato et al., 2006; Cabrera et al., 2003; Henriques et al., 2003; Andreasen \& Bishara, 1970; Bishara \& Andreasen, 1970). Other factors also influence both the clinical performance of these materials and changes in their color, such as extended exposure to water, enzymes, diet and temperature variation (Oliveira et al., 2011; Martins et al., 2006; Von Fraunhofer et al. 1992; DeGenova et al., 1985).

Knowledge of the changes in mechanical properties of elastomeric chains is of great interest, since they will remain for a long period in the oral cavity and, during this interval, should continue to deliver a clinically adequate force. Thus, the present study aimed to evaluate the initial force and its degradation, as well as the staining of esthetic elastomeric chains of four commercial brands.

\section{Methodology}

The study evaluated esthetic elastomeric chains, color Crystal, medium force, divided into 4 different groups according to their commercial brands, namely Group 1 Eurodonto (Curitiba, PR); Group 2 Morelli (Sorocaba, SP); Group 3 Orthometric (Marília, SP); and 3M Group 4 (Sumaré, SP); from sealed packages and within the expiration date.

In the Figure 1 it is possible to visualize the packages of each brands of esthetic elastic chains that were evaluated in the present research.

Figure 1. Medium-force esthetic elastomeric chains of 3M, Orthometric, Morelli and Eurodonto brands.

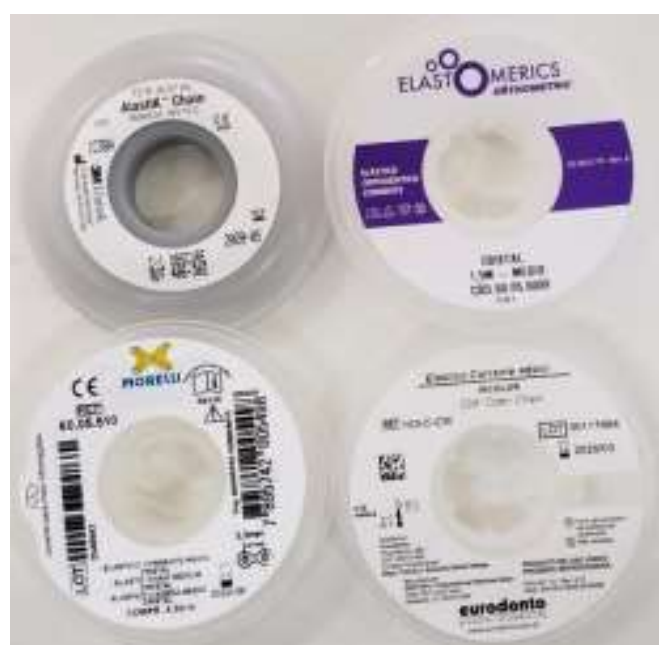

Source: Authors.

Each group consisted of 10 segments of 6 links of elastomeric chains extended twice their length, which corresponds to $30 \mathrm{~mm}$, maintained by simple devices with two metal tips to secure the elastics, simulating the continuous use of elastics by the patients. Then, the force was measured using a Zeusan precision orthodontic dynamometer (São Paulo, SP) and recorded on a Microsoft ${ }^{\circledR}$ Excel spreadsheet. After that, these devices securing the elastics were immersed in artificial saliva. The containers were kept in an oven at $37^{\circ} \mathrm{C}$, simulating the oral environment. After the periods of 1, 7, 14, 21 and 30 days, the forces were again measured and recorded. 
Figure 2. Devices for elastics stretching, containing 4 groups of different brands with 10 esthetic elastomeric chains and devices to secure the elastics immersed in artificial saliva and kept in an oven at $37^{\circ} \mathrm{C}$.

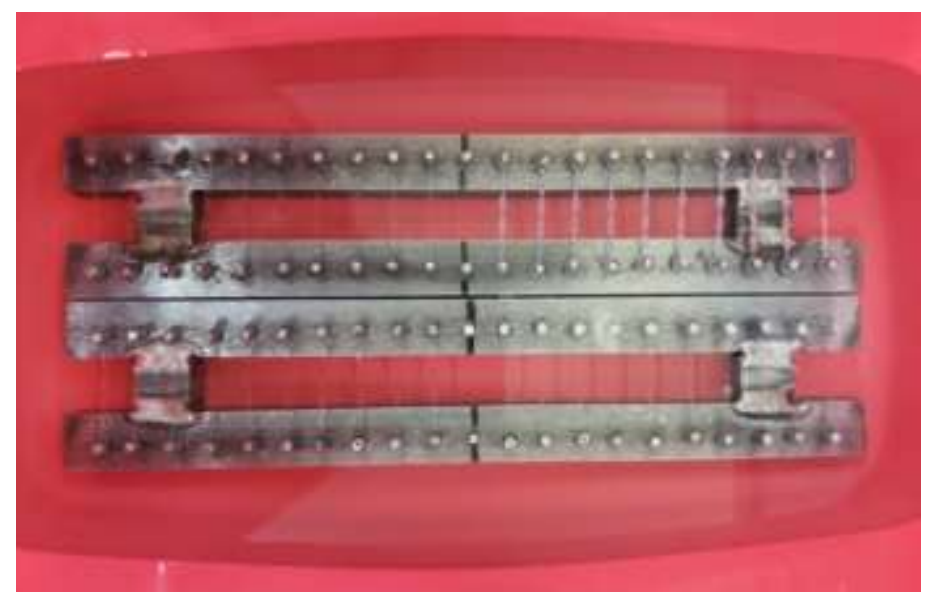

Source: Authors.

The Figure 2 shows the device that was used to keep de elastsic chains stretched for the requested period. Observe that all elastic had the same amount of stretch.

Also, before study onset and after the 30-day period, when the elastics were discarded, photographs were taken using a mobile device (cell phone), on a white background, of 3 randomly selected samples of each commercial brand to observe color changes (Figure 3). This color change was assessed subjectively by 31 examiners who evaluated the photographs using a visual analogue scale (VAS) in the Mentímeter remote interactive presentation software. The examiners marked the degree of color change of rubber bands for each group on a scale from 1 to 10 . This scale consisted of a $10-\mathrm{cm}$ horizontal line, with number one at the left end representing no color change and the right end (10) indicating the greatest degree of color change of rubber bands. The brand of elastomeric chains was kept confidential to avoid any influence on the final decision of examiners.

Figure 3. Images of the samples of elastomeric chains of each commercial brand before and after 30 days of study to evaluate the color change.

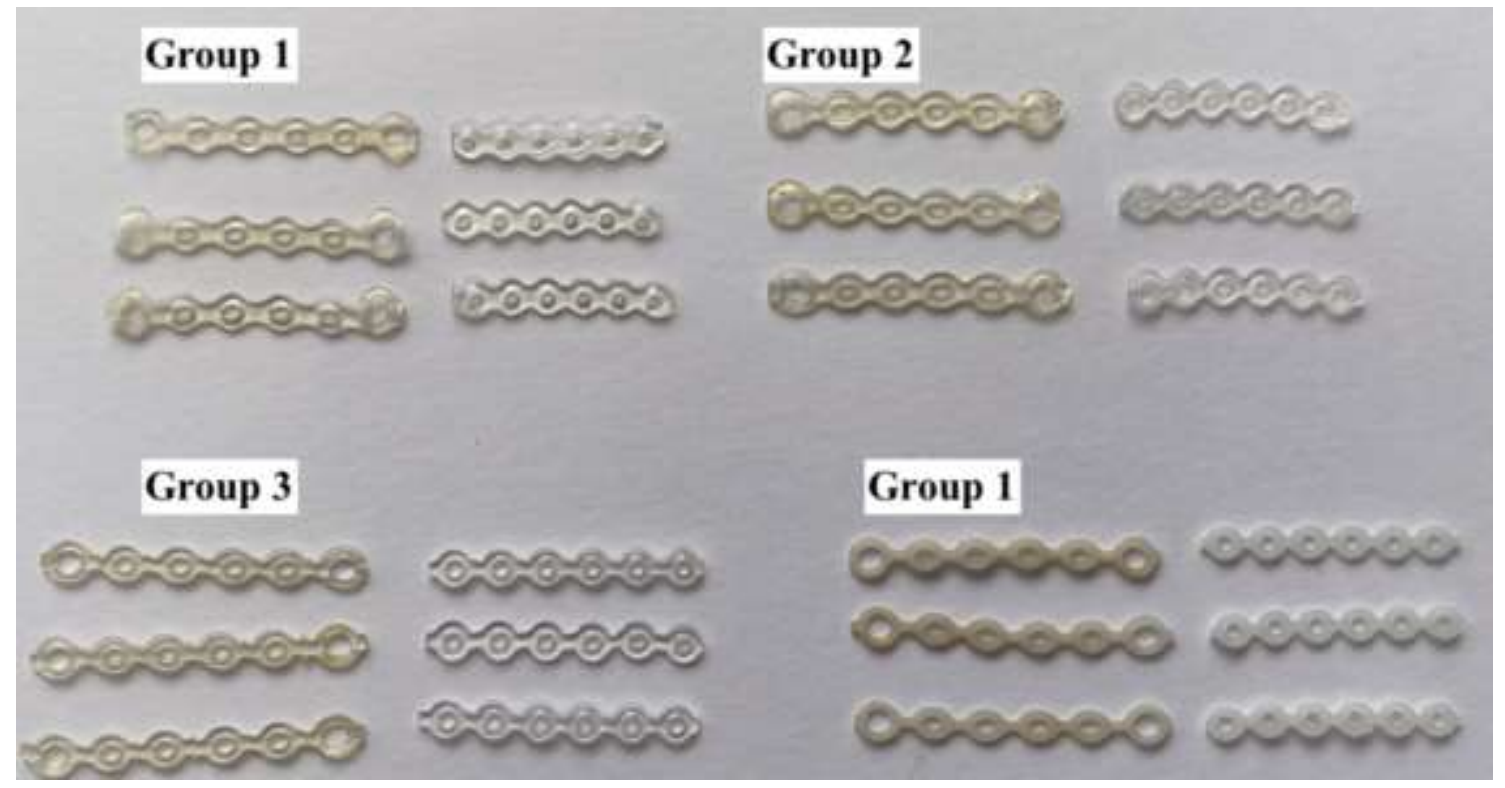

Source: Authors. 
In the Figure 3, despite some difference among brands, it is interest to note that all elastic chains had some color degradation after the evaluation period.

\section{Statistical analysis}

Data from the collected information were organized in a table in Excel format (Microsoft Office Excel, Redmond, WA, USA), submitted to the SigmaPlot software (SigmaPlot, San Jose, CA, USA) version 13.0 and analyzed in relation to the normal distribution (Shapiro-Wilk test). Data were evaluated by the Analysis of Variance (ANOVA) test for two factors, time and groups. The Tukey test was used for analyses of multiple comparisons. A significance level of 5\% was adopted for the analyses. The study power was evaluated and for comparisons between groups, intervals, and groups vs. intervals, considering an alpha value of 1.0 .

\section{Resultss}

After completion of the 30-day period of elastomeric chains immersed in artificial saliva in an oven simulating the oral cavity, it was observed that no elastic was ruptured.

Table 1 presents the forces measured for each brand at different time intervals. It is observed that the brand whose elastomeric chains showed the greatest initial force was Eurodonto (384g), followed by Morelli (334g), Orthometric (282g) and $3 \mathrm{M}(247 \mathrm{~g})$. At completion of 30 days, the Eurodonto and Morelli elastics showed the highest residual force (144.5g), followed by elastomeric chains of the brands Orthometric $(110 \mathrm{~g})$ and $3 \mathrm{M}(105 \mathrm{~g})$.

Tabela 1. Evaluated mean force (grams) and standard deviation for each elastic chain brand group for observed period of time.

\begin{tabular}{|c|c|c|c|c|c|c|c|c|}
\hline \multirow{2}{*}{$\frac{\text { Period/Brand }}{\text { Days }}$} & \multicolumn{2}{|c|}{$3 \mathrm{M}$} & \multicolumn{2}{|c|}{ Orthometric } & \multicolumn{2}{|c|}{ Morelli } & \multicolumn{2}{|c|}{ Eurodonto } \\
\hline & Mean & SD & Mean & $\mathrm{SD}$ & Mean & SD & Mean & SD \\
\hline & $247,00^{\mathrm{aA}}$ & 10,59 & $282,00^{\mathrm{aA}}$ & 16,86 & $334,00^{\mathrm{aA}}$ & 41,41 & $384,00^{\mathrm{aA}}$ & 3,16 \\
\hline & $160,50^{\mathrm{bB}}$ & 8,95 & $163,50^{\mathrm{bB}}$ & 8,83 & $188,00^{\mathrm{bB}}$ & 13,78 & $221,50^{\mathrm{bB}}$ & 11,06 \\
\hline & $131,50^{\mathrm{cC}}$ & 6,68 & $139,00^{\mathrm{cC}}$ & 7,37 & $172,50^{\mathrm{cC}}$ & 11,11 & $183,00^{\mathrm{cC}}$ & 10,59 \\
\hline 1 & $122,50^{\mathrm{cC}}$ & 6,34 & $128,00^{\mathrm{cC}}$ & 6,74 & $160,00^{\mathrm{dD}}$ & 7,07 & $178,00^{\mathrm{cC}}$ & 7,88 \\
\hline 2 & $111,00^{\mathrm{cC}}$ & 8,75 & $116,50^{\mathrm{cC}}$ & 5,29 & $154,50^{\mathrm{dD}}$ & 4,97 & $157,50^{\mathrm{dD}}$ & 6,34 \\
\hline 3 & $105,50^{\mathrm{cC}}$ & 9,84 & $110,00^{c C}$ & 9,84 & $144,50^{\mathrm{dD}}$ & 6,43 & $144,50^{\mathrm{eE}}$ & 7,24 \\
\hline
\end{tabular}

ABCDE: Elastic chain grups force decay intergroup analysis for each time period (ANOVA_Two Factor Repetition). Vertical analysis in which different letters represent significative difference among groups in a same time period. Equal letters represent that there is no significance difference $(\mathrm{p}<0,001)$.

abcde: Elastic chain grups force decay intragroup analysis for each time period (ANOVA_Two Factor Repetition). Vertical analysis in which different letters represent significative difference among groups in a same time period. Equal letters represent that there is no significance difference $(\mathrm{p}<0,001)$.

Source: Authors.

Detailed analysis of intragroup data in each period revealed that the $3 \mathrm{M}$ group showed significant difference between means in all comparisons for time 0 and 1 ( $\mathrm{p}<0.001$ ). However, there was no significant difference in comparisons between 7 vs. 14,14 vs. 21 and 21 vs. 30 (p>0.05), i.e., 3M elastics showed significant reduction only until day 7, corresponding to a loss of $46.76 \%$ of force. Similarly, the Orthometric group showed difference between all comparisons of times 0 and 1 ( $\mathrm{p}<0.001$ ), 
and no significant difference was found in the comparison of periods: 7 vs. 14,14 vs. 21,21 vs. 30 (p>0.05), also evidencing force degradation of $50.7 \%$ after 7 days. In the Morelli group, all comparisons of times (0, 1 and 7) showed significant difference ( $p<0.05$ ), except for periods 21 vs. 30 days and 14 vs. 21 ( $>>0.05$ ), with a force degradation of $48.35 \%$ after 7 days. Finally, in the Eurodonto group, all comparisons showed significant difference, except for period 7 vs. 14 days ( $\mathrm{p}=0.317$ ), with a force degradation of $52.34 \%$ in the first 7 days. Table 1 also evidences that, only after 14 days, there was statistically significant difference in the amount of residual force between Morelli elastomeric chains and other brands. On day 21, 3M and Orthometric elastomeric chains showed similar values, yet significantly different from Morelli and Eurodonto, which in turn did not present difference between them. Finally, after the 30-day period, only 3M and Orthometric elastomeric chains did not show any significant difference.

Graph 1 shows the percentage of force dissipation of elastomeric chains of each brand. After the first day, elastics of all brands had lost more than $40 \%$ of their initial force, except for the 3M elastic, whose residual force was $64.98 \%$. For Orthometric, Eurodonto and Morelli elastomeric chains, this value was 57.98, 57.68 and 56.28, respectively. After one week, the $3 \mathrm{M}$ elastomeric chain still had the greatest amount of force, namely 53.25\%. However, in this period, the Morelli elastic was the closest, with a residual force of $51.64 \%$. Orthometric and Eurodonto presented $49.29 \%$ and $47.66 \%$ of residual force, respectively. On day 21, the elastomeric chains of all brands had already lost more than half of their initial force, with Morelli presenting the highest percentage of remaining force (46.25\%), followed by $3 \mathrm{M}(44.94 \%)$, Orthometric (41.31\%) and Eurodonto (41.02\%). Finally, after 30 days of evaluation, Morelli and $3 \mathrm{M}$ had the greatest amount of force $(43.26 \%$ and $42.71 \%$, respectively). Elastomeric chains of other brands reached day 30 with 39\% (Orthometric) and 37.63\% (Eurodonto).

Graph 1. Percentage of residual force of the different elastics evaluated as a function of time (days).

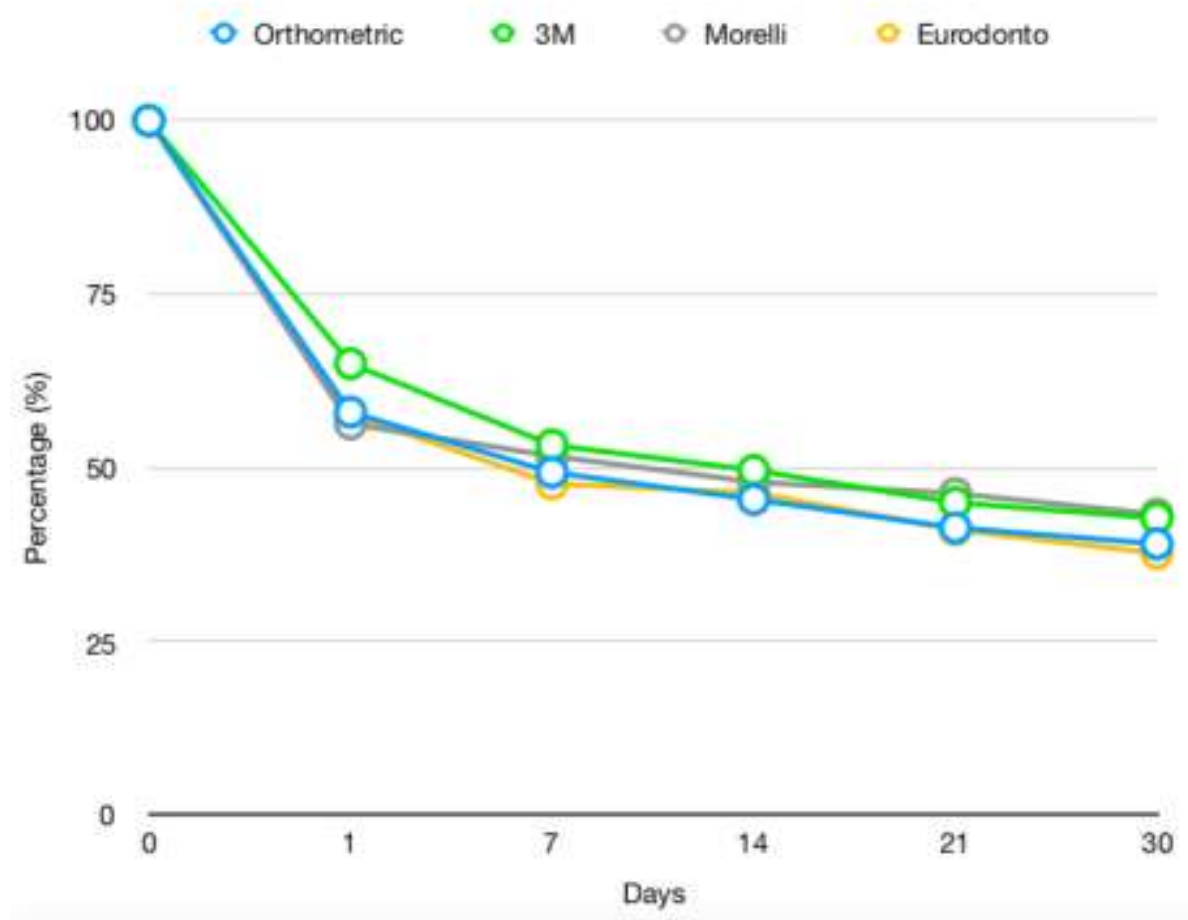

Source: Authors. 
Graph 2 presents the mean color degradation of elastomeric chains after the 30-day period. This graph evidences, by the mean scores assigned by examiners on the VAS, that $3 \mathrm{M}$ elastics presented the greatest change (8.1), followed by Morelli (6.1) and Orthometric elastics (5.6). Eurodonto elastomeric chains showed the lowest color degradation (5).

Graph 2. Color change of the different elastics evaluated after the 30-day period. 10

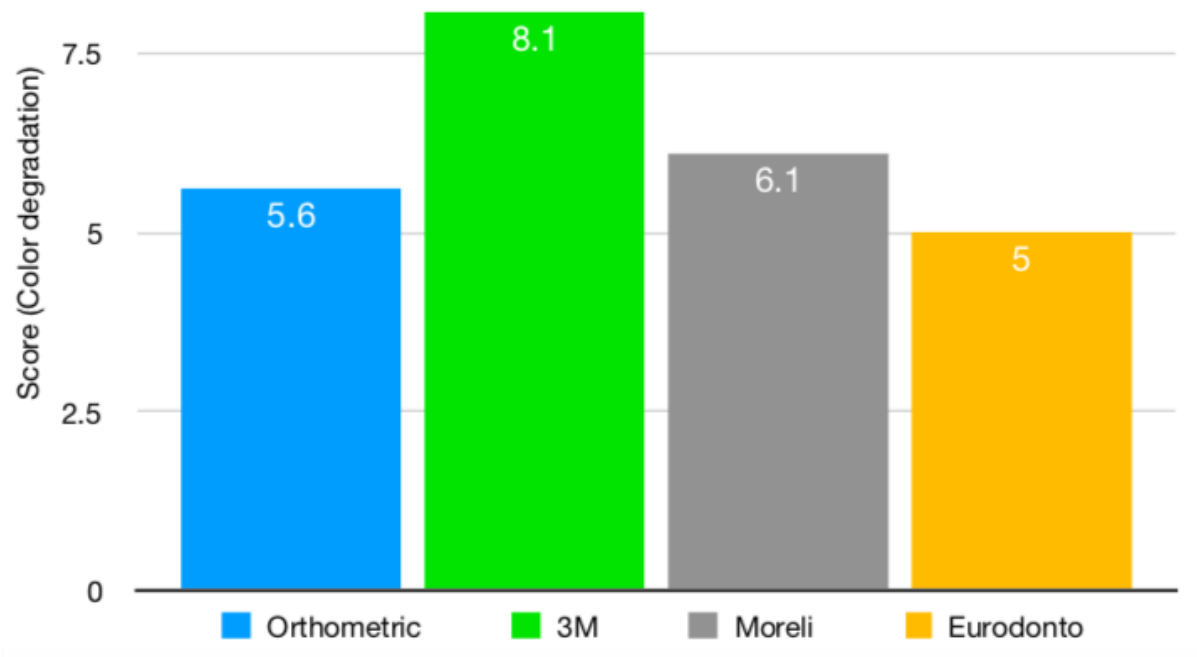

Source: Authors.

Statistical analysis revealed that $3 \mathrm{M}$ vs Eurodonto, $3 \mathrm{M}$ vs Orthometric and $3 \mathrm{M}$ vs Morelli showed significant difference between them, while Morelli vs Eurodonto, Morelli vs Orthometric and Orthometric vs Eurodonto did not. These results can be observed on Table 2 .

Table 2. Non-parametric test color degradation (mean) intergroup analysis.

\begin{tabular}{r|cccc}
\hline \multicolumn{1}{c|}{ Tempo/Marca } & $3 \mathrm{M}$ & Orthometric & Morelli & Eurodonto \\
\hline $3 \mathrm{M}$ & & $\mathrm{a}$ & $\mathrm{a}$ & $\mathrm{a}$ \\
Orthometric & $\mathrm{a}$ & $\mathrm{b}$ & $\mathrm{b}$ \\
Morelli & $\mathrm{b}$ & $\mathrm{b}$ & $\mathrm{b}$ & \\
Eurodonto & $\mathrm{c}$ & $\mathrm{b}$ & $\mathrm{b}$ & \\
\hline
\end{tabular}

Source: Authors.

\section{Discussion}

Knowledge on changes in the mechanical properties of elastomeric chains has great interest for orthodontists, since these accessories will remain for a long time in the oral cavity and, during this period, they continue to deliver a clinically adequate force (Alexandre et al., 2008; Baty et al., 1994). Due to the large number of commercial brands with different prices in the market, the use of one brand or another should primarily be based on the characteristics of mechanical efficiency 
associated with the best esthetic performance during the interval between sessions (Santos et al., 2009).

This study compared the amount of force dissipated by esthetic elastomeric chains from four different commercial brands and the force degradation over time, besides the color change of these elastomers. According to the literature, elastomeric chains tested in a wet environment experience greater force degradation over time compared to testing in a dry environment (Ferriter et al., 1990; Huget et al., 1990; Ash \& Nikolai, 1978), and are also influenced by the temperature of the medium, whose increase worsens the reduction of generated load (Wang et al., 2007; Stevenson \& Kusy, 1994). Thus, this study employed an environment as close as possible to the oral cavity. For thar purpose, the elastomeric chains were immersed in artificial saliva stored at $37^{\circ} \mathrm{C}$ in an oven, simulating its continuous use by the patients.

The results were analyzed and revealed a gradual decrease in forces released by elastomeric chains throughout the study. However, the greatest degradation occurred after the first day. After this period, the magnitude of force degradation was smaller and maintained a pattern for all groups during the study. Similar findings were also observed in other studies (Alexandre et al., 2008; Baty et al., 1994; Huget et al., 1990; Ash \& Nikolai, 1978) that observed that the greatest reduction in the amount of load generated by elastomeric chains occurred in the first hour of testing, 30\% in the average. For this reason, it is recommended to apply an initial force greater than desired for a given orthodontic movement, aiming to compensate for this force reduction during the continuous use of elastics (Fernandes et al., 2011; Moris et al., 2009; Loriato et al., 2006; Cabrera et al., 2003; Henriques et al., 2003; Andreasen \& Bishara, 1970; Bishara \& Andreassen, 1970).

Buchsmann et al. (2012) compared 8 brands of elastomeric chains and observed that, after 21 days, the mean residual force was $50.2 \%$, with the residual force for $3 \mathrm{M}$ being $46.07 \%$; this result is close to the present findings. After 21 days of evaluation, the percentage of residual force of $3 \mathrm{M}$ elastics was $44.94 \%$.

In 2015, after comparing 19 elastomeric chains of different brands, Aldrees et al. (2015) observed that 3M esthetic chains had an initial force of $287 \mathrm{~g}$ and, after 30 days, $49.8 \%$ residual force. These values are similar to the present study, in which $3 \mathrm{M}$ elastomeric chains initiated the evaluation with a mean force of $247 \mathrm{~g}$ and residual force, after 30 days, of $42.71 \%$.

When observing the residual force obtained in the different time intervals, it was observed that Morelli elastics showed the greatest amount of residual force (43.26\%) at completion of 30 days (Graph 1), dissipating 334g in the average at the onset of evaluation (Table 1). This result differs from that obtained in a study conducted in 2008 (Alexandre et al., 2008). In that study, the authors found that Morelli elastomeric chains released an initial force of approximately $200 \mathrm{~g}$, with a residual force of $29 \%$ after 30 days. However, it should be mentioned that such study evaluated gray elastomeric chains, different from our study that compared esthetic elastomeric chains.

This study also aimed to compare the color change of elastomeric chains at completion of 30 days, a period when elastomeric chains are usually changed following the orthodontic treatment protocol. Thus, it is also fundamental to assess whether the color change of elastics compromises their esthetics, since esthetic accessories are increasingly asked by patients who wish to be treated with the most imperceptible devices as possible (Aldrees et al., 2015; Cavalcante et al., 2013).

Thus, after the study period (30 days) when elastomeric chains were removed from the support immersed in saliva, 3 samples of each brand were randomly selected and photographed together with 3 intact samples from the packages. These photographs of elastomeric chains before and after the study were evaluated by 31 examiners, who assessed subjectively using a visual analogue scale to verify the color change.

Based on the evaluation of images of the 4 groups of elastomeric chains, it is evident that only exposure to artificial saliva for 30 days already caused changes in color. The $3 \mathrm{M}$ elastomeric chains showed the greatest degradation of their 
original color. This result agrees with different studies that, comparing the color stability of esthetic elastomeric chains of different brands, reported that 3M elastics presented the greatest changes (Aldrees et al., 2015; Cavalcante et al., 2013).

Considering the present findings and from a clinical standpoint, it can be concluded that, regardless of the brand, esthetic elastomeric chains present significant force dissipation after 24 hours, without significant difference between brands. However, all clear esthetic elastomeric chains are susceptible to significant color changes in the oral environment, which may bother more demanding patients in relation to the appliance esthetics. Considering that esthetic brackets have a high cost in relation to metallic brackets, and assuming that patients who accept to pay this extra cost are concerned with the appearance of the appliance, the accessories must also be carefully chosen to meet this esthetic demand. In this sense, $3 \mathrm{M}$ elastics had worse performance, and at least in vitro these results suggest the indication of other brands. Also, dental professionals must be aware of the restrictions and guidelines to be provided to the patient to avoid some types of food that can stain and change the color of clear elastomeric chains (Cavalcante et al., 2013; Loriato et al., 2006; Martins et al., 2006; Henriques et al., 2003).

\section{Conclusion}

All elastics showed force degradation over time, regardless of the brand.

After 1 day, all brands showed force degradation around $40 \%$ of their initial force.

The color change occurred for all elastics and was similar between them, except for 3M elastics, which showed greater change in relation to the other brands tested.

\section{References}

Alexandre, L. P., Oliveira Junior, G., Dressano, D., Paranhos, L. R., \& Scanavini, M. A. (2008). Avaliação das propriedades mecânicas dos elásticos e cadeias elastoméricas em ortodontia. Revista de Odontologia da Metodista, 16 (32), 53-6.

Ash, J. L., \& Nikolai, R. J. (1978). Relaxation of orthodontic elastomeric chains and modules in vitro and in vivo. Journal of Dental Research, 57(5-6), 685690 .

Andreasen, G. F., \& Bishara, S. E. Comparison of alastik chain with elastics involved with intra-arch molar to molar forces. (1970). The Angle Orthodontist, 40 (3), 151-158.

Aldrees, A. M., Al-Foraidis, S. A., Murayshed, M. S., \& Almoammar, K. A. (2015) Color stability and force decay of clear orthodontic elastomeric chains: an in vitro study. International Orthodontics, 13 (3), 287-301.

Baty, D. L., Volz, J. E., \& Von Fraunhofer, J. A. (1994). Force delivery properties of colored elastomeric modules. American Journal of Orthodontics and Dentofacial Orthopedics. 106 (1), 40-46.

Bishara, S. E., \& Andreasen, G. F. (1970). A comparison of time related forces between plastic alastiks and latex elastics. The Angle Orthodontist. 40 (4), 319328.

Buchmann, N., Senn, C., Ball, J., \& Brauchli, L. (2012) Influence of initial strain on the force decay of currently available elastic chains over time. The Angle Orthoddontist, 82 (3), 529-35.

Cabrera, M. D. C., Cabrera, C. A. G., Henriques, J. F. C., de Freitas, M. R., \& Janson, G. (2003). Elastic in orthodontics: behavior and clinical application. Dental Press Journal of Orthodontics, 8 (1), 115-129.

Cavalcante, J. S., Barbosa, M. C., \& Sobral, M. C. (2013). Evaluation of the susceptibility to pigmentation of orthodontic esthetic elastomeric ligatures. Dental Press Journal of Orthodontics, 18 (2), 20.e1-8.

DeGenova, D. C., Mcinnes-Ledoux, P., Weinberg, R., \& Shaye, R. (1985). Force degradation of orthodontic elastomeric chains: a product comparison study. American Journal of Orthodontics and Dentofacial Orthopedics, 87 (5), 377-384.

Fernandes, D. J., Fernandes, G. M. A., Artese, F., Elias, C. N., \& Mendes, A. M. (2011). Force extension relaxation of medium force orthodontic latex elastics. The Angle Orthodontist, 81 (5), 812-819.

Ferriter, J. P., Meyers Junior, C. E., \& Lorton, L. (1990). The effect of hydrogen ion concentration on the force-degradation rate of orthodontic polyurethane chain elastics. American Journal of Orthodontics and Dentofacial Orthopedics, 98 (5), 404-410. 
Research, Society and Development, v. 10, n. 4, e54310414307, 2021

(CC BY 4.0) | ISSN 2525-3409 | DOI: http://dx.doi.org/10.33448/rsd-v10i4.14307

Henriques, J. F. C., Hayasaki S. M., \& Henriques, R. P. (2003). Elásticos ortodônticos: como selecioná-los e utilizá-los de maneira eficaz. Jornal Brasileiro de Ortodontia e Ortopedia Facial, 8 (48), 471-475.

Huget, E. F., Patrick, K. S., \& Nunez, L. J. (1990). Observations on the elastic behavior of a synthetic orthodontic elastomer. Journal of Dental Research, 69 (2), 496-501.

Loriato, L. B., Machado, A. W., \& Pacheco, W. (2006). Considerações clínicas e biomecânicas de elásticos em Ortodontia. Revista Clínica de Ortodontia Dental Press, 5 (1), 42-55.

Mandall, N. A., Vine, S., Hulland, R., \& Worthington, H. V. (2006) .The impact of fixed orthodontic appliances on daily life. Community Dental Health, 23 (2), 69-74.

Martins, M. M., Mendes, A. M., Almeida, M. A. O., Goldner, M. T. A., Ramos, V. F., \& Guimarães, S. S. (2006). Comparative study of diferente colors of molded elastomeric ligatures. Dental Press Journal of Orthodontics, 11 (4), 81-90.

Moris, A., Sato, K., Facholli, A. F. D. L., Nascimento, J. E., \& Sato, F. R. L. (2009). In vitro study of the force degradation of latex orthodontic elastics under dybamuc conditions. Dental Press Journal of Orthodontics, 14 (2), 95-108.

Oliveira, C. B., Vieira, C. I. V., Ribeiro, A. A., Caldas, S. G. F. R., Martins, L. P., Gandini Jr, L. G., et al. (2011) Degradação de forças dos elásticos intermaxilares ortodônticos sintéticos. Ortodontia, 44 (5), 427-432.

Santos, R. L., Pithon, M. M., Mendes, G. S., Romanos, M. T. V., \& Ruellas, A. C. O. (2009). Cytotoxicity of intermaxillary orthodontic elastics of different colors: an in vitro study. Journal of Applied Oral Sciences, 17 (4), 326-329.

Stevenson, J. S., \& Kusy, R. P. (1994). Force application and decay characteristics of untreated and treated polyurethane elastomeric chains. The Angle Orthodontist, 64 (6), 455-466.

Tweng, J. M., Campbell, W. K., \& Freeman, E. C. (2012). Generation differences in young adult's life goals, concern for others, and civic orientation, 19962009. Journal of Personality and Social Psychology, 102 (5), 1045-62.

Von Fraunhofer, J. A., Coffelt, M. T., \& Orbell, G. M. (1992). The effects of artificial saliva and topical fluoride treatments on the degradation of the elastic properties of orthodontic chains. The Angle Orthodontist, 62 (4), 265-274.

Wang, T., Zhou, G., Tan, X., Dong, Y. (2007). Evaluation of force degradation characteristics of orthodontic latex elastics in vitro and in vivo. The Angle Orthodontist, 77 (4), 688-693.

Zhang, M., McGrath, C., Hagg, U. (2008). Changes in oral health-related quality of life during fixed orthodontic appliance therapy. American Journal of Orthodontics and Dentofacial Orthopedics, 133 (1), 25-9. 